Division of Geological \& Geophysical Surveys

RAW-DATA FILE 2015-2

\title{
SINGLE-BEAM BATHYMETRY DATA COLLECTED IN SHALLOW-WATER AREAS NEAR GAMBELL, GOLOVIN, HOOPER BAY, SAVOONGA, SHISHMAREF, AND WALES, ALASKA, 2012-2013
}

by

Nicole E.M. Kinsman

$\$ 2.00$

March 2015

THIS REPORT HAS NOT BEEN REVIEWED FOR

TECHNICAL CONTENT OR FOR CONFORMITY TO THE EDITORIAL STANDARDS OF DGGS

Released by

STATE OF ALASKA

DEPARTMENT OF NATURAL RESOURCES

Division of Geological \& Geophysical Surveys

3354 College Road

Fairbanks, Alaska 99709-3707 
Western Alaska LCC

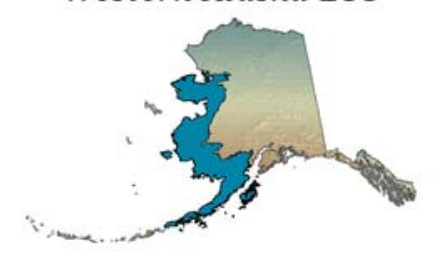

Western Alaska Landscape

Conservation Cooperative

(WALCC)

Final Project Report

\section{PROJECT INFORMATION}

\begin{tabular}{|c|c|}
\hline Title & $\begin{array}{l}\text { Nearshore Bathymetric Data Collection in the Vicinity of Western } \\
\text { Alaska Communities }\end{array}$ \\
\hline Project ID & WALCC 2012-5 \\
\hline Author of report & nicole.kinsman@alaska.gov \\
\hline Principal Investigator & $\begin{array}{l}\text { Nicole Kinsman } \\
\text { Alaska Division of Geological \& Geophysical Surveys (DGGS) } \\
\frac{\text { nicole.kinsman@alaska.gov }}{(907) 451-5026}\end{array}$ \\
\hline Partner & $\begin{array}{l}\text { Alaska Ocean Observing System (AOOS) } \\
\text { Contact: Molly McCammon, Director }\end{array}$ \\
\hline Project period & June 18, 2012, through December 31, 2014 \\
\hline Report submission date & January 15, 2015 \\
\hline Award number & Single Source Grant F12AC00536 - USFWS/DGGS \\
\hline With support from & $\begin{array}{l}\text { U.S. Fish and Wildlife Service (USFWS) } \\
\text { Western Alaska Landscape Conservation Cooperative (LCC) } \\
\text { Coastal Impact Assistance Program (CIAP) } \\
\text { Alaska Division of Geological \& Geophysical Surveys (DGGS) } \\
\text { Alaska Ocean Observing System (AOOS) }\end{array}$ \\
\hline Key words & $\begin{array}{l}\text { Western Alaska, bathymetry, sonar, nearshore, water depths, } \\
\text { soundings, DEM }\end{array}$ \\
\hline
\end{tabular}
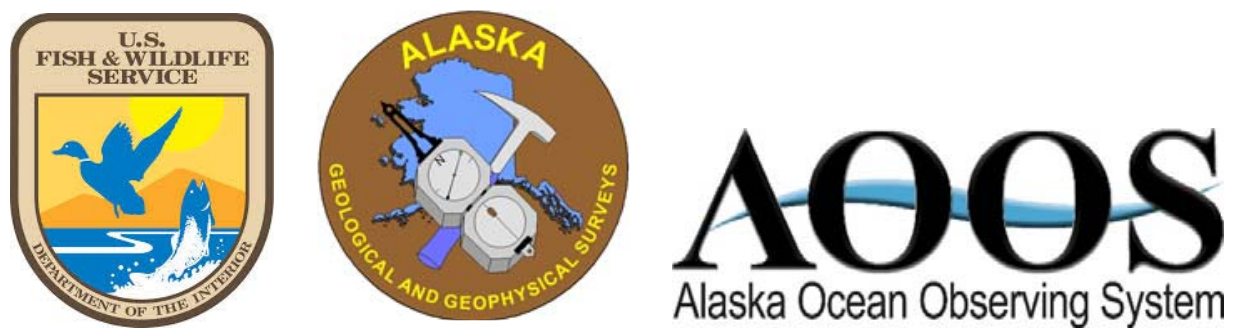


\title{
SINGLE-BEAM BATHYMETRY DATA COLLECTED IN SHALLOW-WATER AREAS NEAR GAMBELL, GOLOVIN, HOOPER BAY, SAVOONGA, SHISHMAREF, AND WALES, ALASKA, 2012-2013
}

\author{
by
}

Nicole E.M. Kinsman

Alaska Division of Geological \& Geophysical Surveys

3354 College Rd., Fairbanks, Alaska 99709-3707

nicole.kinsman@alaska.gov

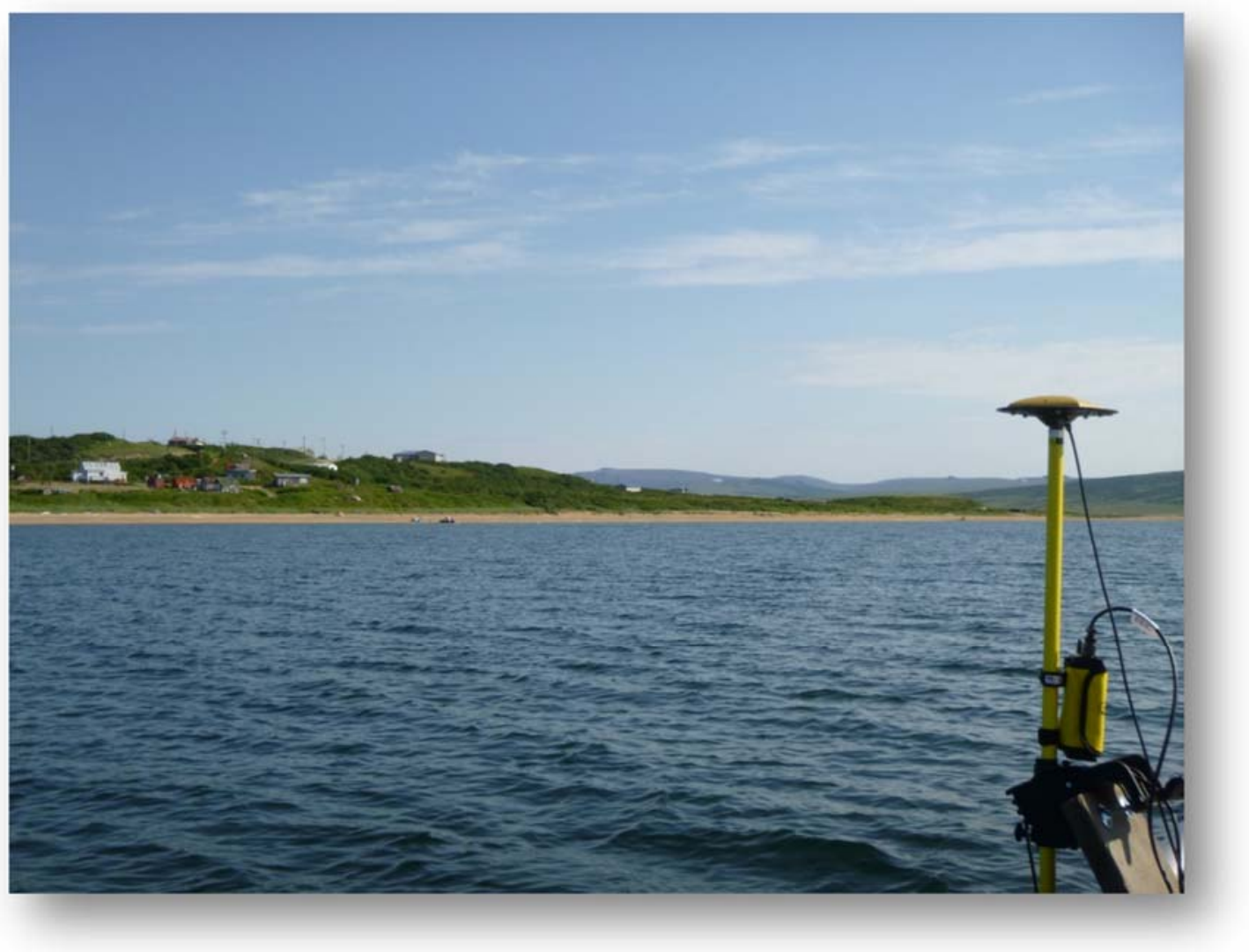

\begin{abstract}
Nearshore bathymetry is a vital link that joins offshore water depths to coastal topography. Seamless water depth information is a critical input parameter for reliable storm surge models, enables the calculation of sediment budgets, and is necessary baseline data for a range of coastal development decisions. Bathymetric data collection capabilities of an active coastal geohazard field program operated by the Alaska Division of Geological \& Geophysical Surveys (DGGS) were expanded in 2012. Resultant datasets presented in this report include nearshore bathymetric measurements of critical shallow-water coastal areas in the vicinity of six western Alaska communities: Gambell, Golovin, Hooper Bay, Savoonga, Shishmaref, and Wales. These data are provided in the form of vector shiptracks and processed singlebeam sounding point clouds. An example of a gridded and interpolated digital depth surface created from these data is provided for Gambell, Alaska. This work was completed with a low-cost, portable sonar system capable of shallow water measurements in rural settings; the system will be maintained for use or loan by DGGS for data collections of this type for the useful life of the equipment.
\end{abstract}




\section{CITATION}

Kinsman, N.E.M, 2015, Single-beam bathymetry data collected in shallow-water areas near Gambell, Golovin, Hooper Bay, Savoonga, Shishmaref, and Wales, Alaska, 2012-2013: Alaska Division of Geological \& Geophysical Surveys Raw Data File 2015-2, 15 p.

\section{INTRODUCTION}

One of the long-recognized gaps in many coastal datasets is water depth directly adjacent to the shoreline. In few places is this more true than in the data-sparse coastal waters of western Alaska. Between the marine depths and onshore elevations lies a critical zone to which traditional ship-based bathymetric surveys do not extend. These areas are best accessed with portable sonar systems attached to small watercraft capable of navigating shallow waters (for example, MacMahan, 2001).

Nearshore bathymetric data is a vital component to understanding how coastal storms impact landscapes because marine energy is dissipated (wave breaking) and transformed (wave refraction, shoaling) as it moves across this zone in high-energy storm events. Community-scale models of coastal storm impacts, tsunami inundation, and other scenario-based coastal hazard mapping require seamless topographic-bathymetric grids of depths and elevations transitioning from the marine to terrestrial environment.

As many communities seek detailed inundation modeling for storm surge preparation and planning purposes, we need to fill gaps in baseline bathymetric data along Alaska's coast. Other uses for nearshore bathymetry include, but are not limited to, expanding our understanding of coastal/inlet dynamics, quantifying alongshore sediment budgets, calibrating bathymetric mapping with remote sensing platforms (Smith and others, 2013), monitoring nearshore benthic environments (for example, in areas of intense dredge mining operations like Nome), and for use in the consideration of barge access to potential community relocation sites (for example, Shishmaref; URS, 2011).

The Alaska Division of Geological \& Geophysical Surveys has an active Coastal Hazards Program tasked with providing the public ready access to sound scientific investigations of coastal processes and geohazard assessments that facilitate the responsible development of Alaska's coastal resources (DGGS, 2015). Previously, this program emphasized the onshore environment, and the scope of nearshore data collection was equipment-limited (lead-line type soundings). This project enhanced the program's ongoing efforts by adding the ability to collect accurate and continuous lines of nearshore bathymetric data.

Primary project objectives:

1. Add the ability to collect accurate and continuous lines of nearshore bathymetric data to ongoing DGGS coastal geohazard investigations.

2. Collect and publish nearshore bathymetric measurements in at least five western Alaska communities by November 20, 2014. 


\section{METHODS}

For navigational purposes, bathymetric surveys are traditionally referenced to a water level datum (for example, Mean Lower Low Water) using tide gages and tide models. Bathymetric measurements referenced to a geodetic reference frame (for example, WGS84) using a Global Positioning System (GPS) are a more accurate way to represent water depths in places with poorly established tidal datums. Previous single-beam bathymetric studies performed at the U.S. Geological Survey (USGS) Center for Coastal and Marine Science have successfully referenced bathymetric measurements to GPS (DeWitt and others, 2012; O’Conner, 2011). This GPS-based approach has been implemented in the acquisition and processing procedures for the datasets included here.

Nearshore bathymetric data collection was undertaken in tandem with ongoing DGGS coastal geohazard mapping activities. For the duration of this project, these activities at DGGS received primary funding from the Coastal Impact Assistance Program (CIAP), which covered fieldwork expenses and staff time for bathymetric measurements collected in the 2012 and 2013 field seasons (fig. 1).

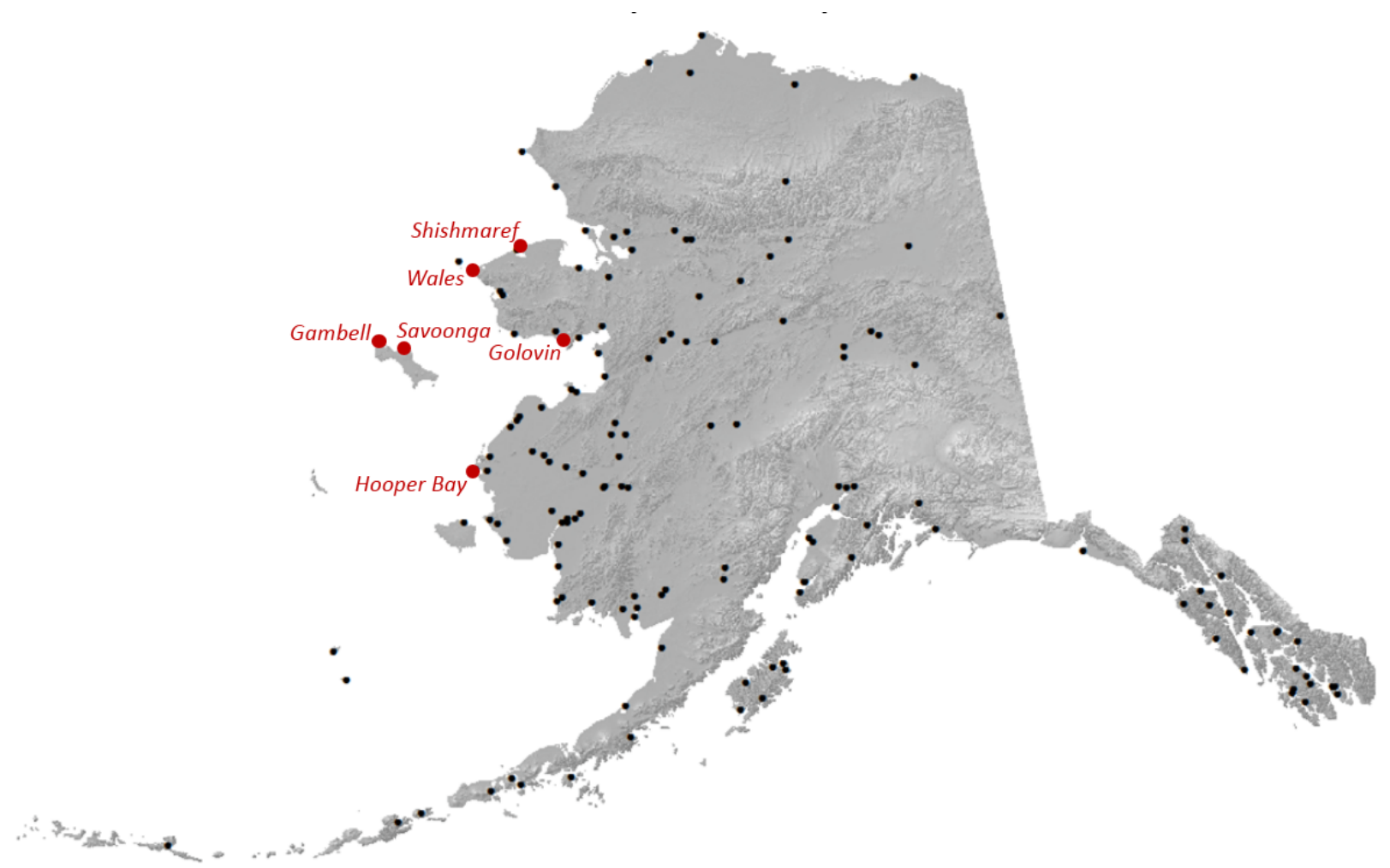

Figure 1. Field locations in Alaska where DGGS collected nearshore bathymetry data during the 2012 and 2013 field seasons.

In each field area, a subset of the DGGS coastal hazards field crew spent one to three days collecting nearshore bathymetric measurements in areas adjacent to existing or proposed coastal development. Shiptracks were designed to be perpendicular to the shore, spaced at an interval appropriate to the opportunistic survey window, and aligned with onshore coastal elevation measurements, when available (see onshore measurements in DGGS, 2014).

Additional depth readings were focused on the mouths of inlets and in tidally-influenced lagoons, river mouths, or estuaries adjacent to developed areas. 
The extended nature of the field campaigns in each community ( $\sim 2$ weeks) allowed bathymetric surveys to be scheduled on-the-fly to coincide with favorable marine conditions over the course of ongoing work. This was an advantage in the unpredictable wave climates of western Alaska, and conducting these surveys in conjunction with longer-term field activities reduced the potential that unfavorable weather could completely prevent data collection. The ability to select for favorable marine conditions also improved final data quality. Despite these long windows for surveying, local weather conditions still did not allow for surveys in some of the field areas that DGGS visited over this project period, such as Port Heiden.

The portable sonar system acquired by this project is an Ohmex SonarMite transducer with associated accessories and software consistent with the widely-used 'Hydrolite' System from Seafloor Systems. The echosounder has a $200 \mathrm{KHz}$ frequency, 4 degree beam width, and a ping rate of 6 Hertz. This equipment was combined with a Topcon DGPS receiver, external antenna, and field controller. Some minor changes were made to the purchased system to make it more appropriate for fieldwork in Alaska; these included transom-mount modifications, replacement of the aluminum pole mount with a steel pole, and extended cables to keep the equipment away from saltwater regardless of what type of boat was used for the survey.

In each community, the bathymetric survey equipment was fitted to boats available on site (fig. 2). Local boat operators were hired to pilot the sensor platforms, allowing our team to benefit from extensive local knowledge of coastal waters, ensure that planned tracks were feasible with the available boat, and maximize the inclusion of known bathymetric features of importance (for example, persistent sandbars). Cooperation with local boat operators also allowed our field crew to engage residents more actively in regional coastal monitoring efforts.

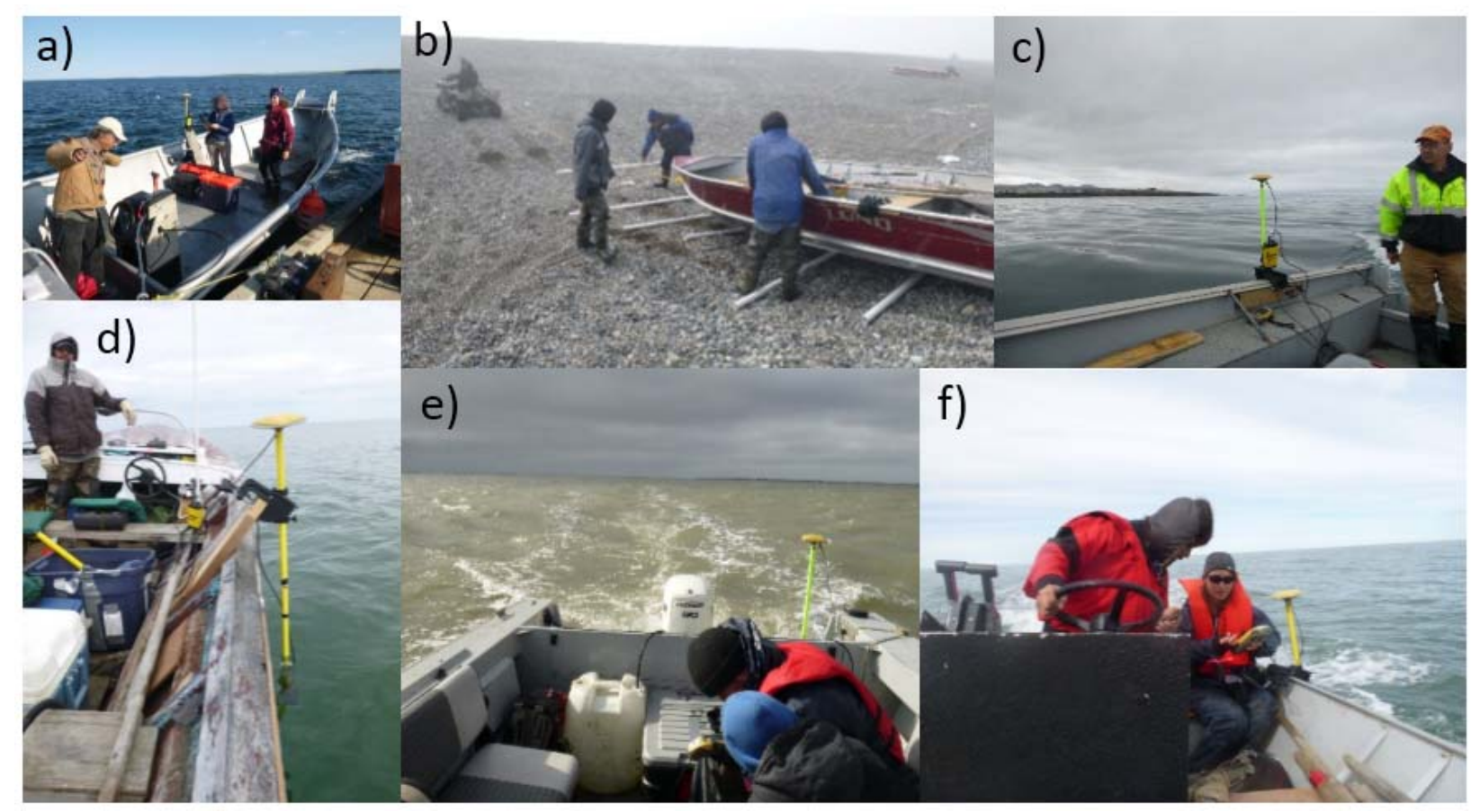

Figure 2. Photographs illustrating some of the many types of local boats and mounts used in the opportunistic bathymetric surveys described in this report. a) Golovin, b) Gambell, c) Savoonga, d) Shishmaref, e) Hooper Bay, and f) Wales. 
In the office, post-survey processing was conducted to correct for sensor position and assess final measurement accuracy. The steps involved in the data collection and post-processing workflow are illustrated in figure 3.

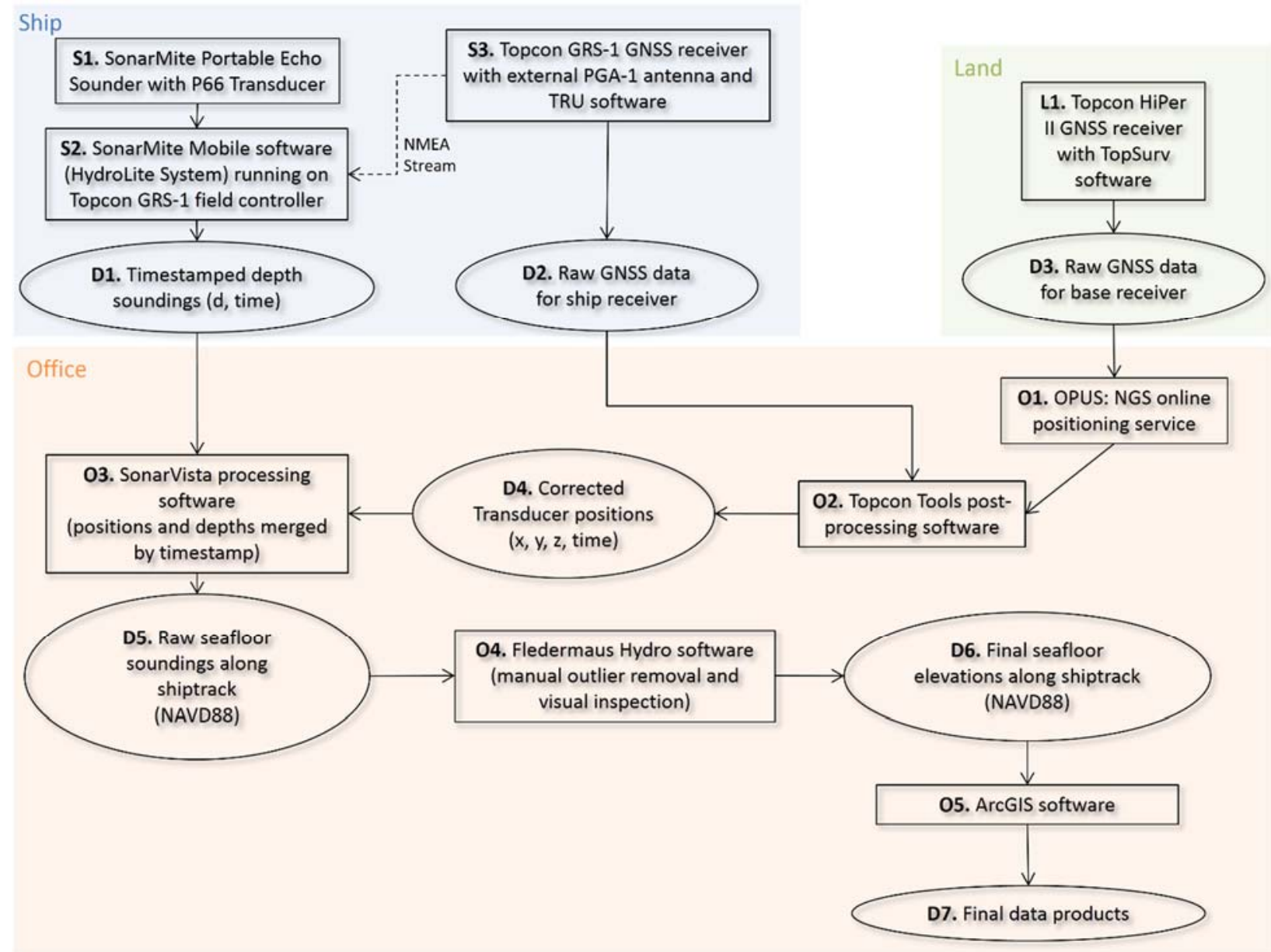

Figure 3. Illustrated workflow of the process steps (rectangles; $S=$ ship, $L=$ land, $O=$ office) and intermediate datasets (ovals; $\mathrm{D}=$ data) involved in the collection and production of the final products included in this raw data release.

Processed data were bundled in GIS-ready shapefiles with appropriate metadata and released as a Raw Data File (RDF) publication through the formal DGGS publication process. For each study area there is a vector shiptrack shapefile and a point cloud of the associated single-beam soundings. All data products associated with this RDF were submitted to the Alaska Ocean Observing System upon publication. 


\section{RESULTS}

NOTE: The data in this RDF are not to be used for navigation. All seafloor elevations are referenced to the NAVD88(GEOID12A) vertical datum.

Datasets included in this report are summarized in table 1; associated shiptrack and local depth sounding maps for each area are illustrated in figures 4-9. The shapefiles for Golovin, Wales, Shishmaref, and Hooper Bay are in NAD83 Alaska UTM Zone 3; Gambell and Savoonga are in UTM Zone 2.

Table 1. Summary of 2012 shiptrack dates, times, locations, and position correction method.

\begin{tabular}{|c|c|c|c|c|}
\hline Date & $\begin{array}{c}\text { Time Start } \\
\text { (AKST) }\end{array}$ & $\begin{array}{c}\text { Time End } \\
\text { (AKST) }\end{array}$ & Correction Method & Sounding Group \\
\hline \multicolumn{5}{|l|}{ GOLOVIN } \\
\hline July 8, 2012 & $12: 15$ & $17: 02$ & CORS corrections $^{1}$ & GLV_01 \\
\hline July 10, 2012 & 09:59 & $12: 39$ & PPK base corrections & GLV_02 \\
\hline \multicolumn{5}{|l|}{ WALES } \\
\hline July 28, 2012 & $11: 55$ & $15: 53$ & PPK base corrections & WAA_01 \\
\hline \multicolumn{5}{|l|}{ SHISHMAREF } \\
\hline August 10,2012 & 09:24 & $12: 23$ & PPK base corrections & SHH10_01 \\
\hline August 10,2012 & 14:04 & $15: 21$ & PPK base corrections & SHH10_02 \\
\hline August 10,2012 & $17: 01$ & 18:03 & PPK base corrections & SHH10_03 \\
\hline August 11,2012 & $10: 14$ & $12: 02$ & PPK base corrections & SHH11_01 \\
\hline August 11,2012 & $12: 28$ & $17: 25$ & PPK base corrections & SHH11_02 \\
\hline August 12,2012 & 09:04 & $11: 54$ & PPK base corrections & SHH12_01 \\
\hline August 12,2012 & $12: 17$ & 13:11 & PPK base corrections & SHH12_02 \\
\hline August 12,2012 & $13: 51$ & 15:06 & PPK base corrections & SHH12_03 \\
\hline August 12,2012 & $15: 38$ & 18:00 & PPK base corrections & SHH12_04 \\
\hline \multicolumn{5}{|l|}{ GAMBELL } \\
\hline July 8, 2013 & $13: 20$ & $15: 29$ & PPK base corrections & GAM_01 \\
\hline \multicolumn{5}{|l|}{ SAVOONGA } \\
\hline July 18, 2013 & 9:58 & $16: 09$ & PPK base corrections & SVA_01 \\
\hline July 19, 2013 & $14: 13$ & $16: 02$ & PPK base corrections & SVA_02 \\
\hline \multicolumn{5}{|l|}{ HOOPER BAY } \\
\hline August 23, 2013 & $14: 36$ & $15: 47$ & PPK base corrections & HPB_01 \\
\hline August 24, 2013 & $15: 47$ & $18: 40$ & PPK base corrections & HPB_02 \\
\hline
\end{tabular}

${ }^{1}$ DGPS base station receiver failed 


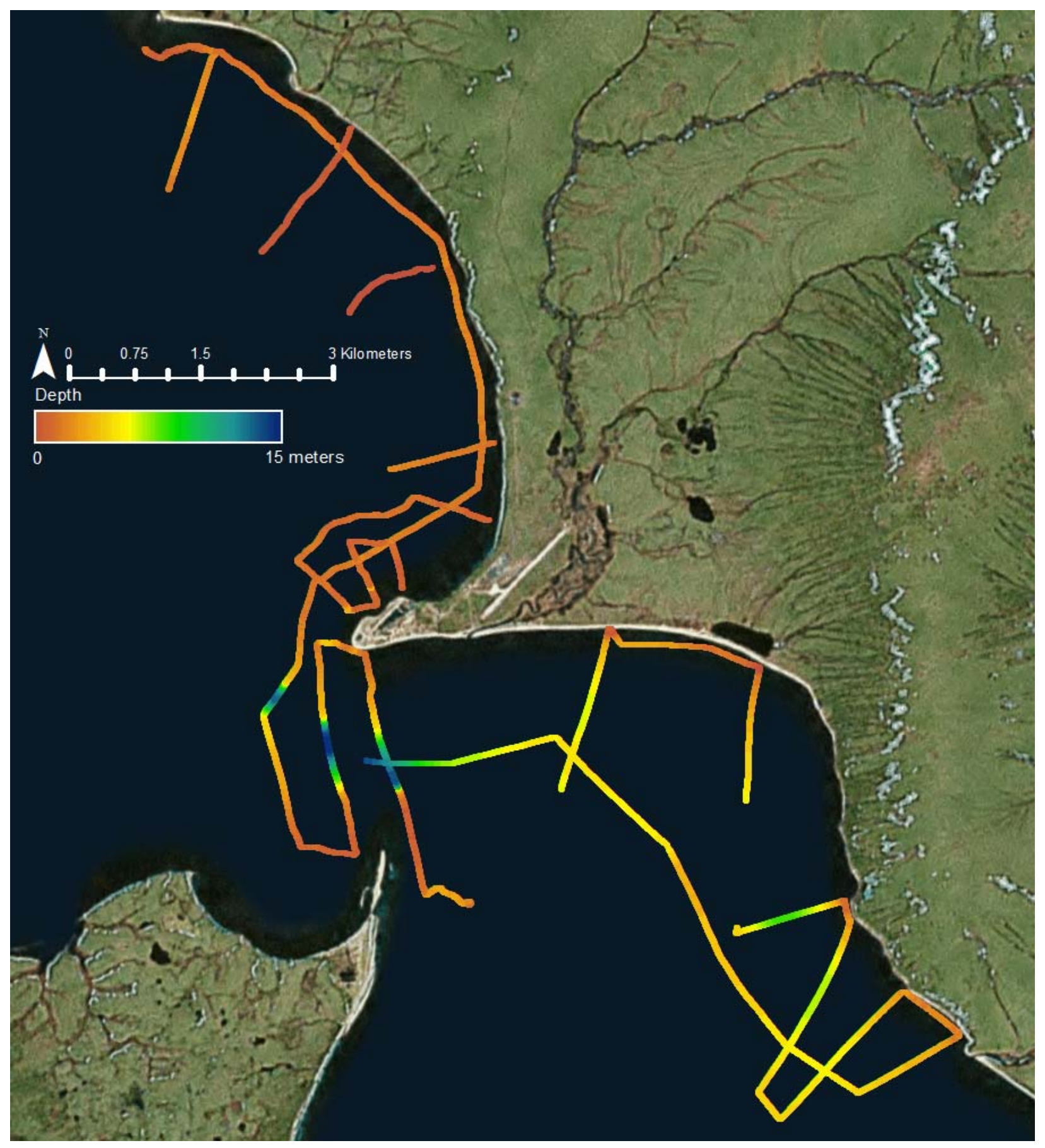

Figure 4. Map of nearshore bathymetry soundings for Golovin, Alaska (July 2012). 


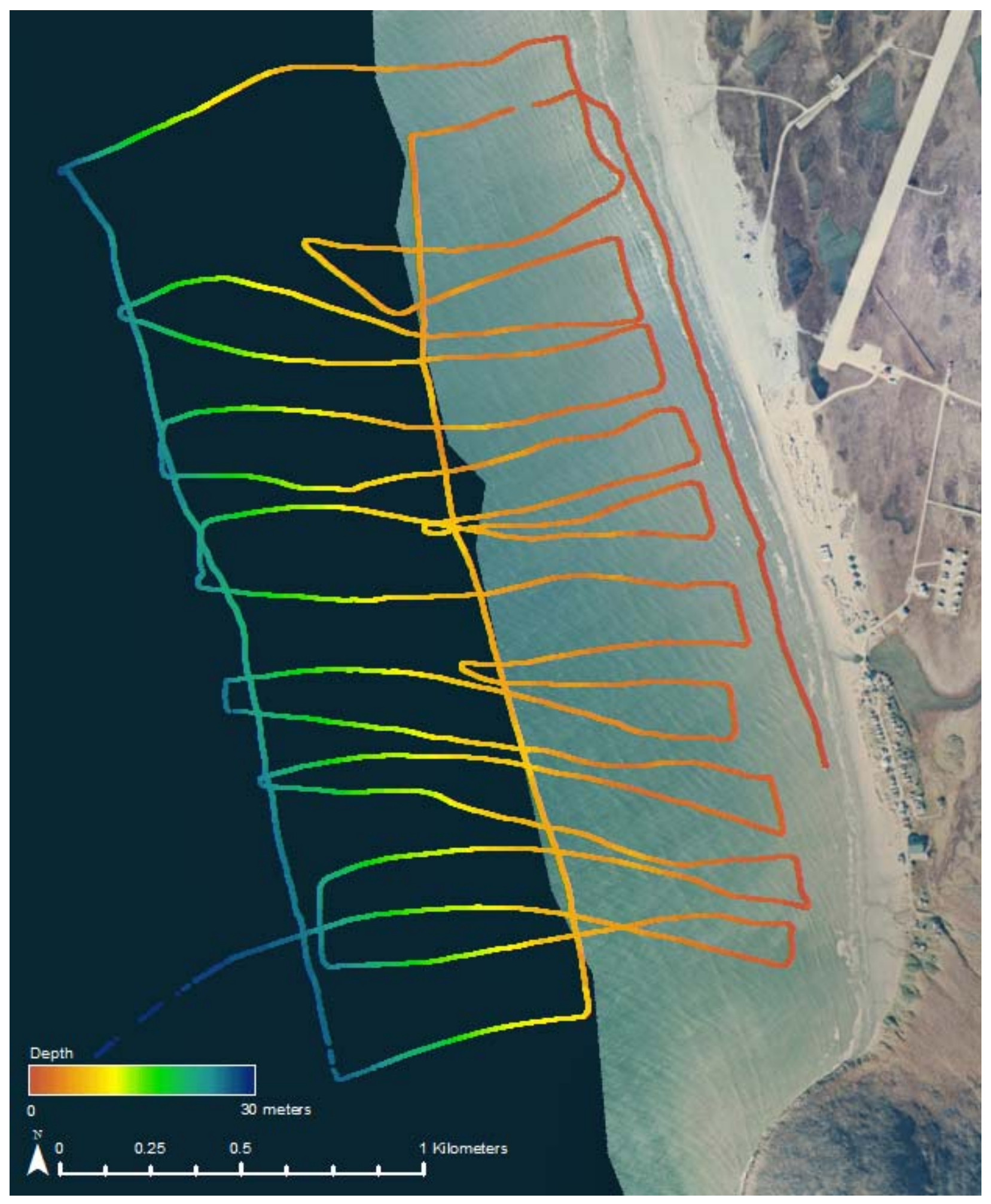

Figure 5. Map of nearshore bathymetry soundings for Wales, Alaska (July 2012). 


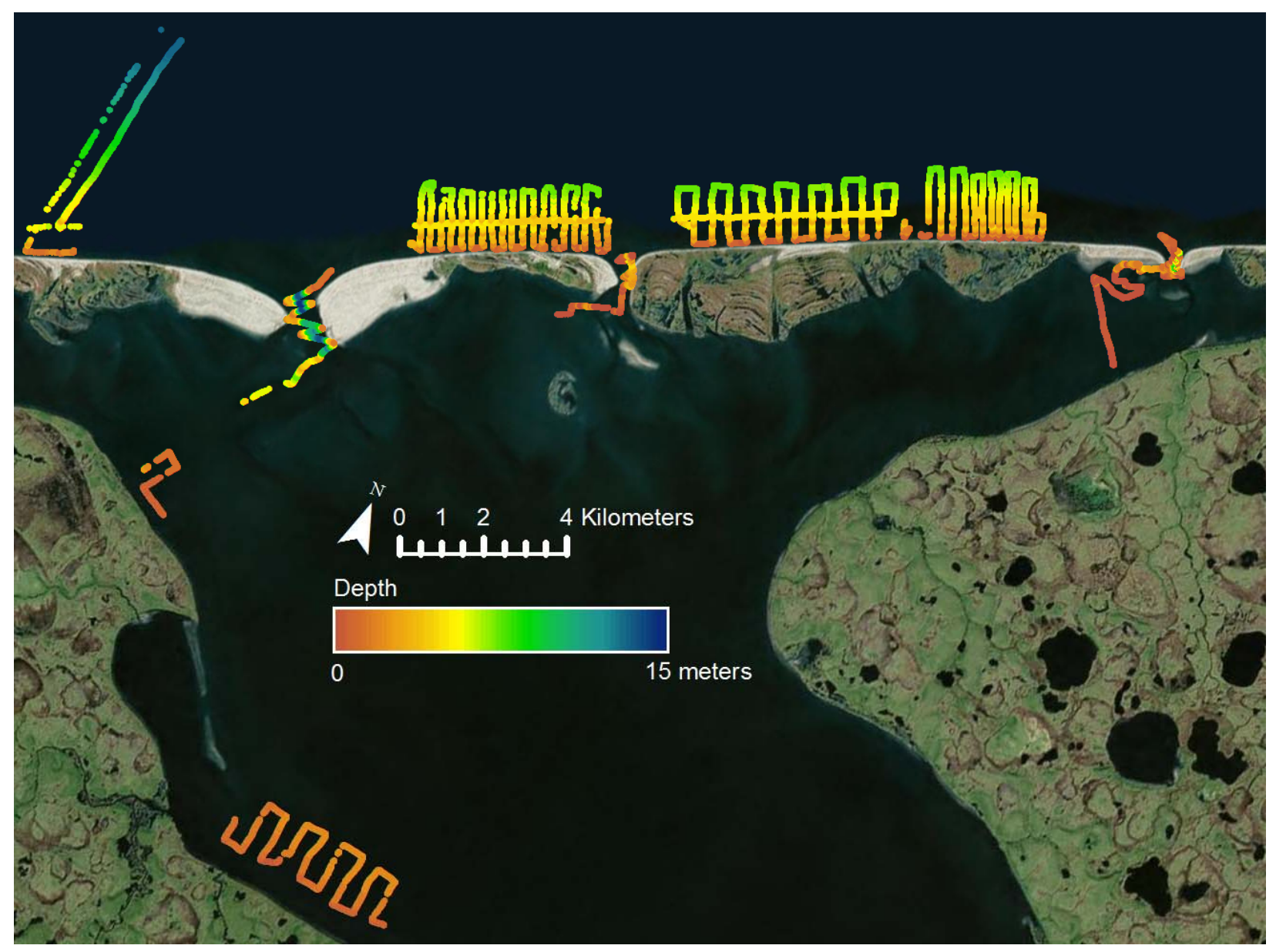

Figure 6. Map of nearshore bathymetry soundings for Shishmaref, Alaska (August 2012).

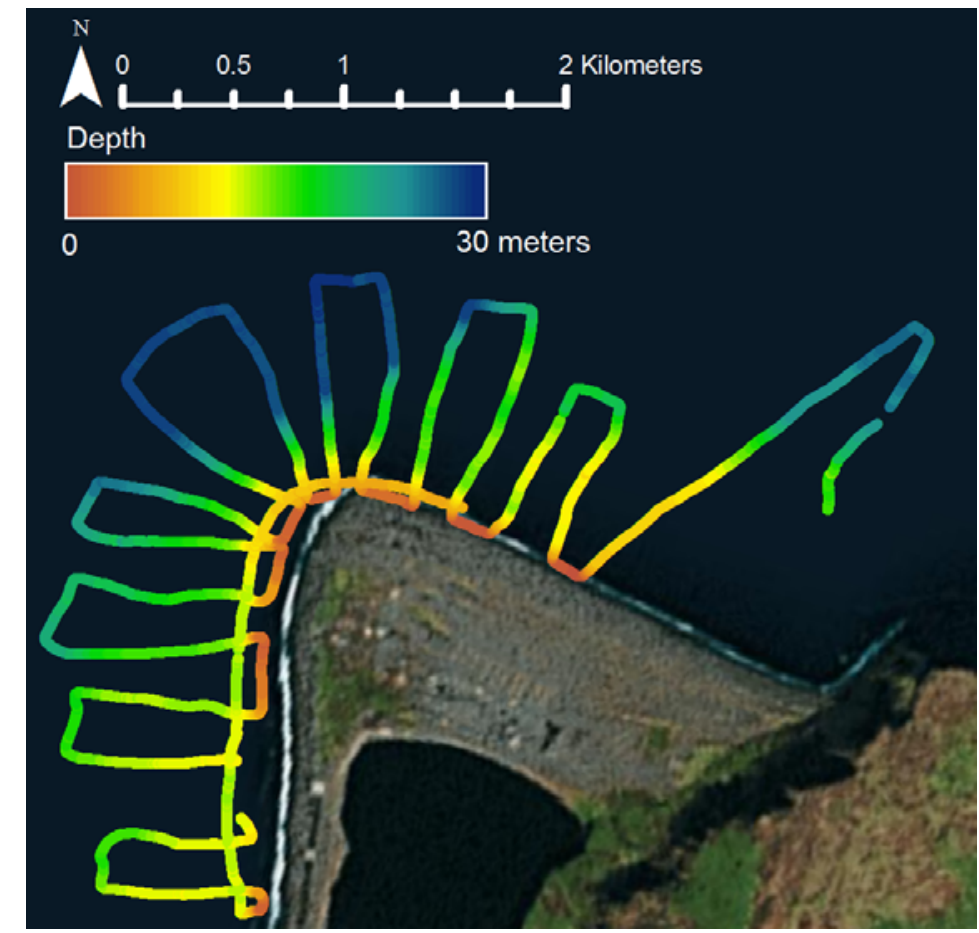

Figure 7. Map of nearshore bathymetry soundings for Gambell, Alaska (July 2013). 




Figure 8. Map of nearshore bathymetry soundings for Savoonga, Alaska (July 2013).

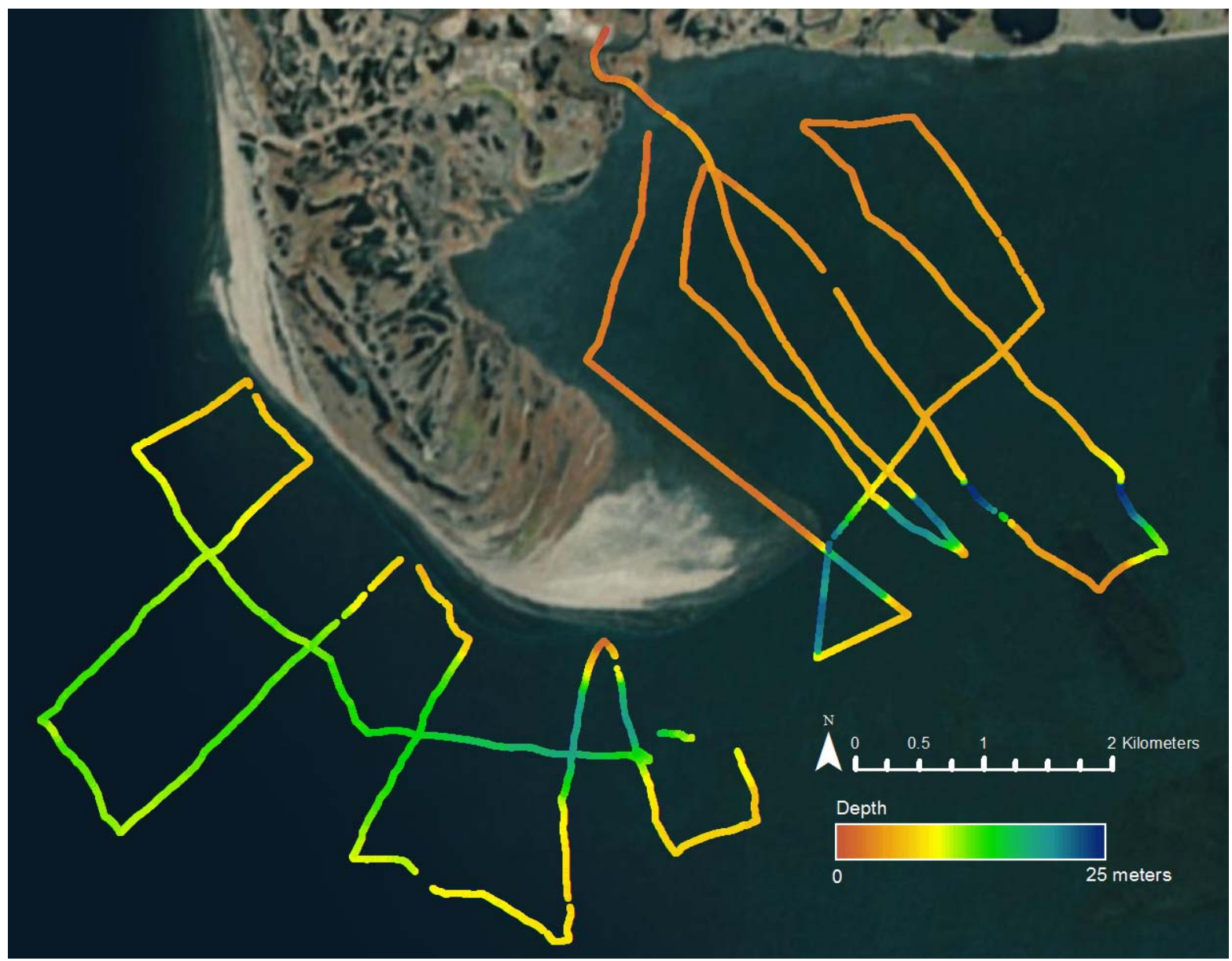

Figure 9. Map of nearshore bathymetry soundings for Hooper Bay, Alaska (August 2013). 
An accuracy assessment was conducted on each included dataset for quality assurance purposes (see table 2 for full results). The vertical Root Mean Square Error (RMSE) is a measure of precision for the soundings based on the crossing zone statistics for all points with a multiple measurement spacing of $<1.5 \mathrm{~m}$ at each shiptrack intersection. Combined uncertainty incorporates the bar check values for the sonar sensor accuracy $(<5 \mathrm{~cm})$ and the accuracy of the post-processed DGPS survey $(<2.5 \mathrm{~cm}$ vertical, except in Golovin; and $<15 \mathrm{~cm}$ horizontal, except in Savoonga).

Table 2. Summary of crossing zone statistics for each sonar sounding point cloud.

\begin{tabular}{|l|c|c|c|c|}
\hline \multicolumn{1}{|c|}{ Location } & $\begin{array}{c}\text { Number of } \\
\text { crossing zones }\end{array}$ & $\begin{array}{c}\text { Vertical RMSE } \\
\text { (soundings; m) }\end{array}$ & $\begin{array}{c}\text { Combined vertical } \\
\text { uncertainty (m) }\end{array}$ & $\begin{array}{c}\text { Combined horizontal } \\
\text { uncertainty (m) }\end{array}$ \\
\hline Golovin & 19 & 0.45 & 0.47 & 0.5 \\
\hline Wales & 51 & 0.11 & 0.12 & 0.1 \\
\hline Shishmaref & 37 & 0.31 & 0.32 & 0.1 \\
\hline Gambell & 14 & 0.19 & 0.20 & 0.1 \\
\hline Savoonga & 93 & 0.58 & 0.58 & $19.7^{1}$ \\
\hline Hooper Bay & 13 & 0.65 & 0.65 & 0.1 \\
\hline
\end{tabular}

${ }^{1}$ High horizontal uncertainty is due to a sonar timestamp registration error, resulting in a possible along-shiptrack displacement of sounding values by up to $19.7 \mathrm{~m}$. Displacement may be much lower along segments of slower vessel speed.

\section{DISCUSSION AND RECOMMENDATIONS}

Conversion of the "bread-crumb"-style sounding data in this RDF to a gridded surface can be challenging due to the disparity in measurement spacing between the along-track and between-track directions. One recommended method to accomplish this uses shore-parallel breaklines to force continuity in the areas between shiptracks in the raster interpolation process. An example of this is shown in figure 10; this interpolated surface was used by USGS researchers to model storm surge and wave runup values for Gambell (Erikson and others, 2015).

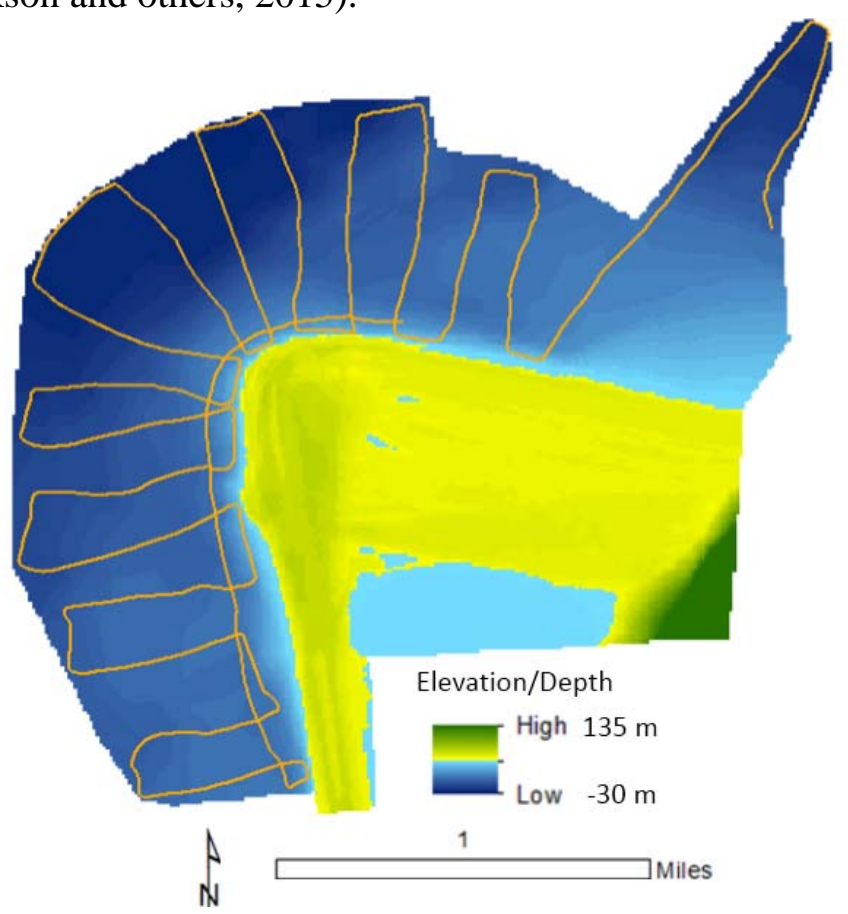

Figure 10. Interpolated raster surface for Gambell based on shiptrack soundings combined with a local digital elevation model for the onshore areas. 
The acquisition of a portable sonar system at DGGS adds value to projects well beyond the scope of this project's objectives. The GPS field controller acquired to run the sonar software is a multipurpose tool, which has greatly expanded non-bathymetry data collection abilities during our field surveys by doubling the number of teams that can collect high-precision elevation data, and greatly increasing our ability to gather additional critical coastal measurements (such as debris-line elevations or nearshore topography).

The system will continue to be maintained by the State of Alaska for the duration of its useful life and may be borrowed by WALCC partners when not in use by DGGS staff. This equipment will continue to be used in coastal mapping projects for the foreseeable future; it also has applications in other settings (for example, to map the bottom of Valdez Glacier lake, fig. 11; Wolken and others, 2015).

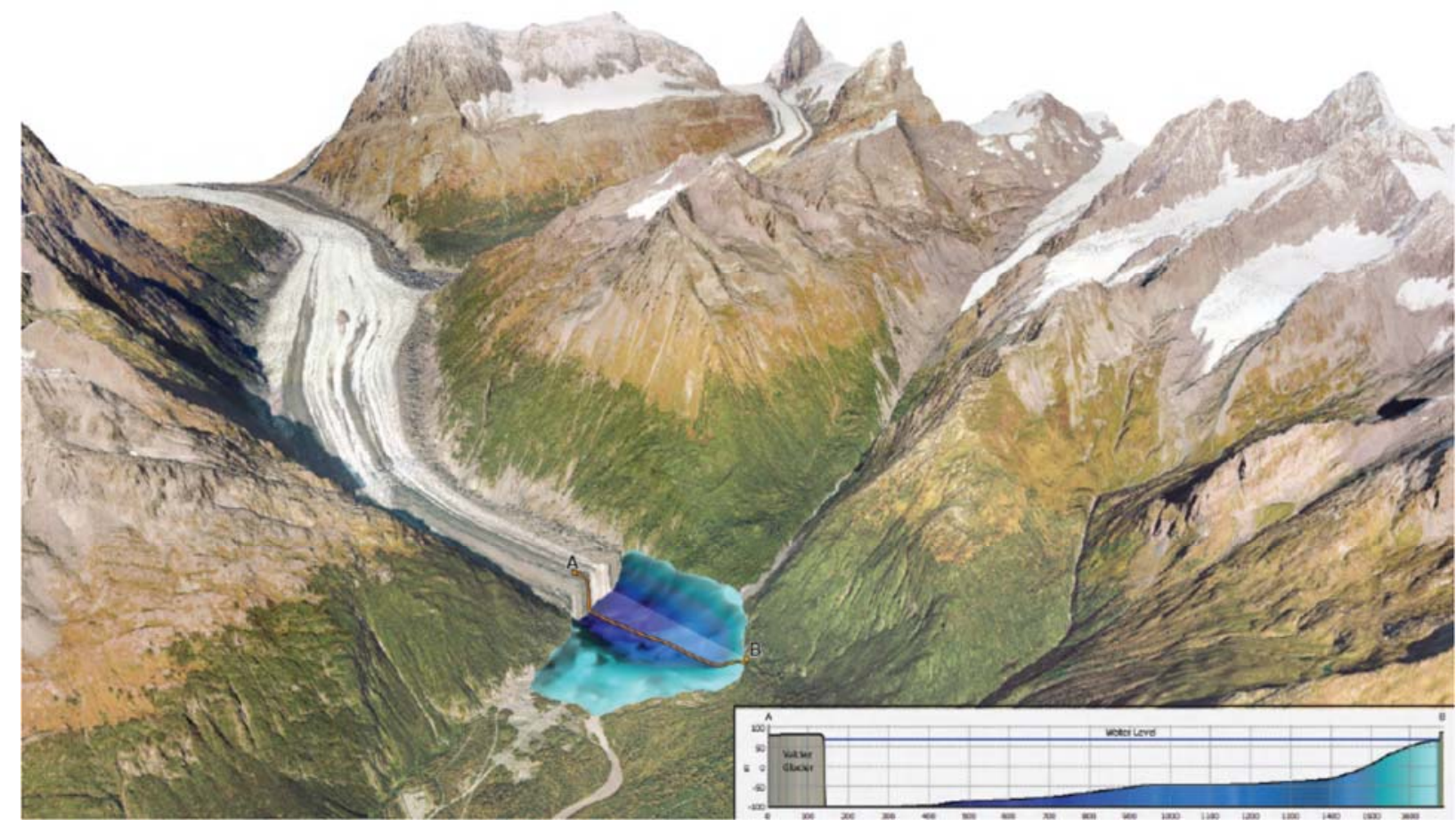

Figure 11. Oblique view of lower Valdez Glacier, Valdez Glacier lake bathymetry, and the glacier foreland (July 2012 bathymetric survey; from Wolken and others, 2015).

Even in geographic regions with excellent coastal data products, nearshore bathymetry remains an elusive yet critical element of many coastal projects. Alaska suffers from significant data gaps in many more basic measurements; this often pushes nearshore bathymetry down in priority even though it is an important component of comprehensive coastal mapping. Therefore, to the extent possible, the opportunistic collection of nearshore bathymetry should remain a priority in the years ahead. 


\section{ACKNOWLEDGMENTS}

In addition to support from the Western Alaska Landscape Conservation Cooperative (WALCC), this project received funding from qualified outer continental shelf oil and gas revenues through the Coastal Impact Assistance Program, U.S. Fish and Wildlife Service, U.S. Department of the Interior. The views and conclusions contained in this document are those of the authors and should not be interpreted as representing the opinions or policies of the Western Alaska Landscape Conservation Cooperative or the U.S. Government. Mention of trade names or commercial products does not constitute their endorsement by the U.S. Government.

Special thanks are extended to our partners at the Alaska Ocean Observing System (AOOS) and to the local residents who worked with us in each community.

DGGS staff and interns that participated in the collection and processing of this data include:

- Meagan DeRaps

- Alexander Gould

- Jacquelyn Overbeck (née Smith)

- Lauren Southerland

Local boat operators include:

- Jack Fagerstrom, Golovin

- Jimmy Seetomona, Shishmaref

- Amos Oxereok, Wales

- Eddie Ungott, Gambell

- Dylan Iya and Bryan Rookok, Jr., Savoonga

- James Hale and Rudy Smith, Hooper Bay 


\section{PRODUCTS TO DATE}

Published materials:

Kinsman, N.E.M, 2015, Single-beam bathymetry data collected in shallow-water areas near Gambell, Golovin, Hooper Bay, Savoonga, Shishmaref, and Wales, Alaska, 2012-2013: Alaska Division of Geological \& Geophysical Surveys Raw Data File 2015-2, 15 p.

Kinsman, N.E.M., and Gould, A.I., 2014, Coastal vulnerability mapping in Alaska: Strategies for small populations in data-sparse regions [poster]: Ocean Sciences Meeting, Honolulu, Hawaii, February 23-28, 2014: Alaska Division of Geological \& Geophysical Surveys, 1 sheet.

doi: $10.14509 / 27202$

Smith, J.R., Kinsman, N.E.M., and Misra, Debasmita, 2013, Using WorldView-2 multispectral bands for shallow-water bathymetric survey near Wales, Alaska (poster): American Society of Photogrammetry and Remote Sensing Annual Meeting, Baltimore, Maryland, March 24-28, 2013 : Alaska Division of Geological \& Geophysical Surveys, 1 sheet. doi: $\underline{10.14509 / 25159}$

Any additional publications directly stemming from this work will be provided to WALCC upon publication.

\section{Presentations:}

"Nearshore bathymetric data collection in the vicinity of western Alaska communities"

Presented by Nicole Kinsman

October 2012

WALCC PI webinar

“Quantifying geologic hazards in Alaska’s coastal communities using GNSS applications”

Presented by Meagan DeRaps

February 2013

Alaska Surveying and Mapping Conference, Anchorage, AK

"An update on geohazard evaluation \& geologic mapping for coastal communities"

Presented by Nicole Kinsman

February 2013

Alaska Forum on the Environment, Anchorage, AK

"How deep are those shoals?"

Presented by Nicole Kinsman

May 2014

WALCC monthly webinar series 


\section{REFERENCES CITED}

DeWitt, N.T., Flocks, J.G., Reynolds, B.J., and Hansen, Mark, 2012, Archive of single-beam bathymetry data collected during USGS cruise 07CCT01 nearshore of Fort Massachusetts and within Camille Cut, West and East Ship Islands, Gulf Islands National Seashore, Mississippi, July 2007: U.S. Geological Survey Data Series 722, 1 CD-ROM. http://pubs.usgs.gov/ds/722/.

DGGS Staff, 2015, Engineering Geology FY15 project descriptions, in DGGS Staff, Alaska Division of Geological \& Geophysical Surveys Annual Report 2014: Alaska Division of Geological \& Geophysical Surveys Annual Report 2014-C, p. 52-67. doi:10.14509/29182

DGGS Staff, 2014, Alaska Coastal Profile Tool (ACPT): Alaska Division of Geological \& Geophysical Surveys Digital Data Series 7. http://maps.dggs.alaska.gov/acpt/ doi:10.14509/27359

Erikson, Li H., McCall, Robert T., van Rooijen, Arnold, and Norris, Benjamin, 2015 [in preparation], Evolution of hind-cast storm events for the St. Lawrence Island and Unalakleet regions in the Bering Sea: U.S. Geological Survey Open File Report, 43 p.

MacMahan, J.H., 2001, Hydrographic surveying from a personal watercraft: Journal of Surveying Engineering, v. 127, no. 1, p. 12-24.

O’Conner, Robert, October 2011, Testing and Implementation of a Portable Sonar System: NOAA fact sheet, 1 p.

Smith, J.R., Kinsman, N.E.M., and Misra, Debasmita, 2013, Using WorldView-2 multispectral bands for shallow-water bathymetric survey near Wales, Alaska (poster)-American Society of Photogrammetry and Remote Sensing Annual Meeting, Baltimore, Maryland, March 24-28, 2013 : Alaska Division of Geological \& Geophysical Surveys, 1 sheet. doi: $\underline{10.14509 / 25159}$

URS Corporation, October 20, 2011, Shishmaref Relocation-Agency Advisory Group Meeting Notes, Anchorage, AK, 6 p.

Wolken, G.J., Arendt, A.A., and Rich, J.L., 2015, Bathymetry of Valdez Glacier lake: Alaska Division of Geological \& Geophysical Surveys Raw Data File 2015-1, 1 sheet. doi:10.14509/29255 